\title{
Lectotypification of two varietal names in Dioscorea glabra (Dioscoreaceae)
}

\author{
Ravikiran S. Pagare 1,3 , Wilson Arisdason ${ }^{2}$, Krishnan Sellappan ${ }^{1}$ \\ and Malapati K. Janarthanam ${ }^{1}$ \\ ${ }^{1}$ Department of Botany, Goa University, Goa 403206, India \\ ${ }^{2}$ Botanical Survey of India, CGO Complex, Salt Lake City, Kolkata 700 064, West Bengal, India \\ ${ }^{3}$ Author for correspondence: ravikiranpagare@gmail.com
}

\begin{abstract}
Lectotypes of Dioscorea glabra Roxb. var. hastifolia Prain \& Burkill and D. glabra Roxb. var. tenuifolia Prain \& Burkill are designated here.
\end{abstract}

\section{Introduction}

Prain and Burkill (1914) described six varieties of Dioscorea glabra Roxb. Among these varieties, D. glabra var. hastifolia Prain \& Burkill is endemic to Andaman Islands and was described based on collections made by Rogers from Rutland, South Andaman, and D. glabra var. tenuifolia Prain \& Burkill was described from Burma (Myanmar). As part of systematic studies on the genus Dioscorea L. in India, original material of D. glabra var. hastifolia were located at CAL ( 3 specimens) and $\mathrm{K}$ ( 1 specimen), all collected by Rogers, and bearing the collection number '278.' Prain and Burkill (1914) did not assign a holotype in the protologue. Therefore, all these four specimens are here considered syntypes. Furthermore, these authors did not cite in which herbaria these specimens were deposited. In December 1983, A.H.M. Jayasuriya annotated the specimen housed at the herbarium at the Royal Botanic Garden Kew (K000098219) as the holotype of D. glabra var. hastifolia. Hoque and Mukherjee (1999) raised D. glabra var. hastifolia to specific rank and gave a new name D. serpenticola Hoque \& P.K. Mukh. because ' $D$. hastifolia' at the rank of species would have become a later homonym of D. hastifolia Nees in J.G.C. Lehmann, Plantae Preissianae 2: 33 (1848). They have designated "South Andaman, Rutland, 19. v. 1904, C.G. Rogers 278" at CAL as 'holotype'; however, there is no annotation by the authors on any of those three sheets available at CAL. Furthermore, it is not clear which herbarium sheet was considered by them as 'holotype.'

Dioscorea glabra var. tenuifolia was described based on collections made by Kurz from Pegu, Yomah (Kurz 2631! three specimens) and by Burkill from Katha, Burma [Myanmar] (Burkill 22656! one specimen). All of these specimens are housed at CAL. The specimens collected by Kurz bear the name as 'D. glabra var. angustifolia' on sheets, but this varietal name was never published. In the protologue, Prain and Burkill did not designate a holotype nor did they mention the name of herbarium where the specimens were housed. Therefore, a lectotype is designated here for D. glabra var. tenuifolia and D. glabra var. hastifolia, which also typifies the name D. serpenticola Hoque \& P.K.Mukh., in accordance with Article 9.2 of the Melbourne Code (McNeill et al. 2012) from among the syntypes. 


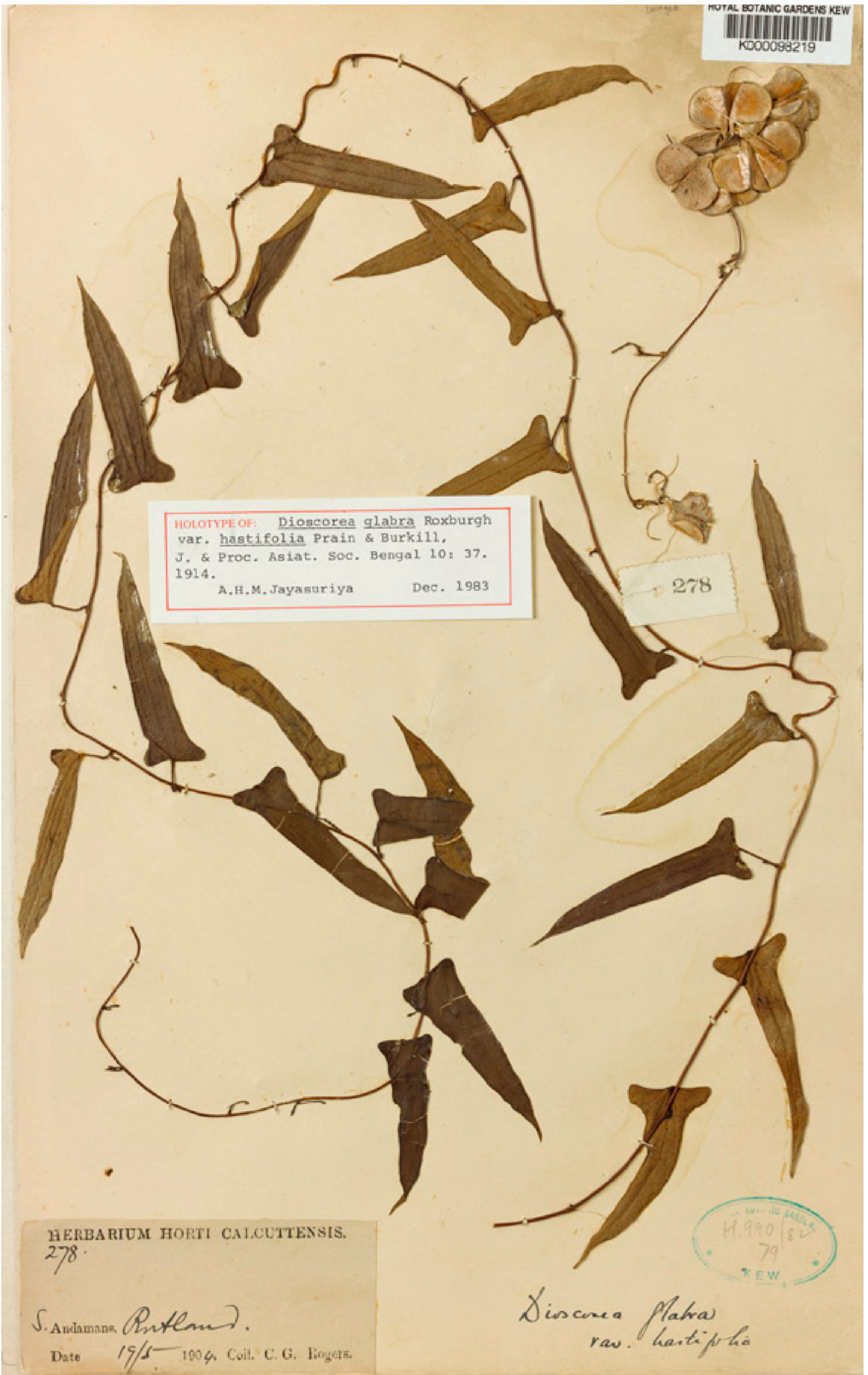

Fig. 1. Lectotype of Dioscorea glabra Roxb. var. hastifolia Prain \& Burkill (=D. serpenticola Hoque \& P.K. Mukh. Rogers 278 (K000098219 image!) (c) The Board of Trustees of the Royal Botanic Gardens, Kew. Reproduced with the consent of the Royal Botanic Gardens, Kew 


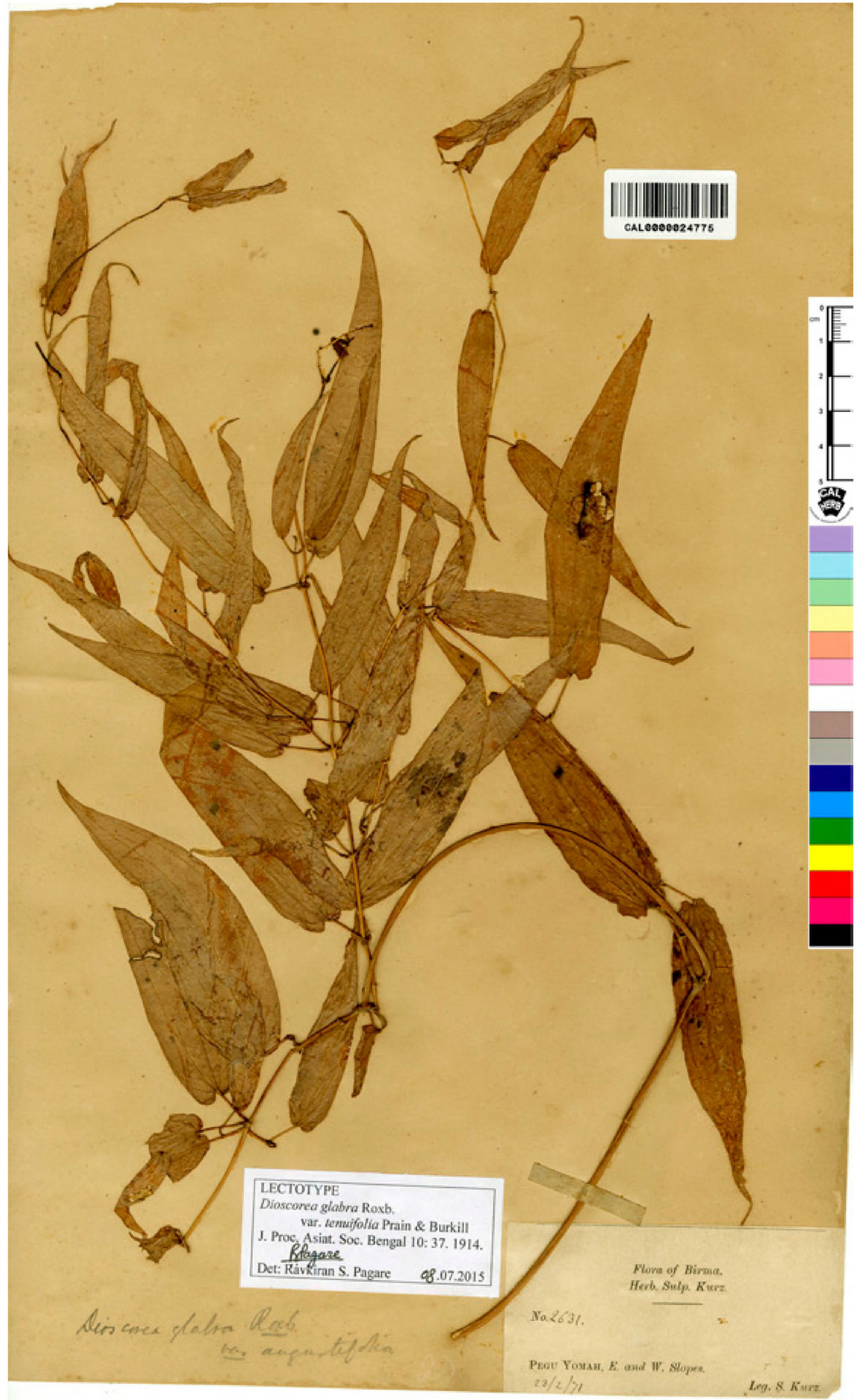

Fig. 2. Lectotype of Dioscorea glabra Roxb. var. tenuifolia Prain \& Burkill, Kurz 2631 (CAL0000024775!) 


\section{Nomenclature}

Dioscorea serpenticola Hoque \& P.K.Mukh., Journal of the Bombay Natural History Society 99(2): 371 (2002).

Dioscorea glabra Roxb. var. hastifolia Prain \& Burkill, Journal and Proceeding of the Asiatic Society of Bengal 10: 37 (1914), non Dioscorea hastifolia Nees, in J.G.C. Lehmann, Plantae Preissianae 2: 33 (1848).

Lectotype (designated here): South Andaman, Rutland, 19 May 1904, Rogers 278 (K000098219, image!); isolecto: CAL!

Dioscorea glabra Roxb. var. tenuifolia Prain \& Burkill, Journal and Proceeding of the Asiatic Society of Bengal 10: 37 (1914).

Lectotype (designated here): [Myanmar] Burma, Pegu Yomah, E. and W. slopes, 23 Feb 1871, Kurz 2631 (CAL0000024775!).

Residual syntype: [Myanmar] Burma, Katha, Burkill R.E.P. 22656 (CAL!)

\section{Acknowledgments}

Authors are grateful to the Board of Trustees of Royal Botanic Gardens, Kew, for permission to publish the images of the selected lectotype and authorities of CAL, for permitting to consult the herbarium. Authors are thankful to Dr. Subir Bandyopadhyay, Scientist, CAL, Howrah, for valuable suggestions. First author (RSP) is thankful to UGC-RGNF (2013-14/RGNF-2013-14-SC-GOA-44299), for the financial assistance.

\section{References}

Hoque A, Mukherjee PK (1999) A new name for Dioscorea glabra var. hastifolia Prain et Burkill from the Andaman and Nicobar Islands, India. Journal of the Bombay Natural History Society 99(2): 371-373

McNeill J, Barrie FR, Buck WR, Demoulin V, Greuter W, Hawksworth DL, Herendeen PS, Knapp S, Marhold K, Prado J, Prud'homme van Reine WF, Smith GF, Wiersema JH, Turland, NJ (2012) International Code of Nomenclature for algae, fungi, and plants (Melbourne Code). Regnum Vegetabile 154 (Koeltz Scientific Books, Königstein)

Prain D, Burkill IH (1914) A synopsis of the Dioscoreas of the old world Africa excluded, with description of new species and varieties. Journal and Proceeding of the Asiatic Society of Bengal 10: 5-41 


\section{$2 \mathrm{BHL}$ Biodiversity Heritage Library}

Pagare, Ravikiran et al. 2015. "Lectotypification of two varietal names in Dioscorea glabra (Dioscoreaceae)." Telopea: Journal of plant systematics 18, 243-246. https://doi.org/10.7751/telopea9072.

View This Item Online: https://www.biodiversitylibrary.org/item/282217

DOI: https://doi.org/10.7751/telopea9072

Permalink: https://www.biodiversitylibrary.org/partpdf/305497

\section{Holding Institution}

The Royal Botanic Gardens and Domain Trust, New South Wales, Australia

\section{Sponsored by}

Atlas of Living Australia

\section{Copyright \& Reuse}

Copyright Status: In copyright. Digitized with the permission of the rights holder.

Rights Holder: The Royal Botanic Gardens and Domain Trust, New South Wales, Australia License: http://creativecommons.org/licenses/by-nc-sa/4.0/

Rights: http://biodiversitylibrary.org/permissions

This document was created from content at the Biodiversity Heritage Library, the world's largest open access digital library for biodiversity literature and archives. Visit BHL at https://www.biodiversitylibrary.org. 